\title{
THE CONSTITUTIONAL RIGHTS TO WATER AND FOOD IN INDONESIA
}

\author{
Luthfi Widagdo Eddyono \\ Mr., Indonesian Constitutional Court, INDONESIA, luthfi_we@yahoo.com
}

\begin{abstract}
The amendment of the 1945 Constitution which was conducted in four stages in 1999, 2000, 2001, and 2002 is crucial. The revision of the 1945 Constitution explicitly not just changed the constitutional system and the mechanism of democracy in Indonesia but also fulfilling the protection of human rights. This paper will collect and examine water and food rights as shown in the Indonesian Constitution after 1999-2002 amendments. Moreover, this paper compares the rights in international perspectives and Indonesia mainly based on the Indonesian Constitutional Court Decision.
\end{abstract}

Keywords: 1945 Constitution, water rights, food rights.

\section{THE AMENDMENT OF 1945 CONSTITUTION}

The original text of the Indonesian Constitution (1945 Constitution) contains 71 points of provisions, ${ }^{1}$ then, after going through four amendments (1999-2002), the material of content of the 1945 Constitution covers 199 points of provisions. ${ }^{2}$ The amendment was conducted gradually and became one of the agendas of the Meetings of the People's Consultative Assembly from 1999 to $2002 .^{3}$ It happened after the resignation of President Soeharto on May 21, $1998 .^{4}$

\footnotetext{
${ }^{1}$ The 1945 Constitution of Indonesia is a short document containing only 37 articles. It was written and reviewed during July and August 1945 by the Committee for Examination of Indonesian Independence (Badan Penyelidik Usaha-usaha Persiapan Kemerdekaan Indonesia or BPUPKI) and the Preparatory Committee for Indonesian Independence (Panitia Persiapan Kemerdekaaan Indonesia or PPKI) and is described in its concluding Additional Provisions as being a temporary document. According to Andrew Ellis, much of the inspiration of its major authors related to the nationalist perspective of Indonesian independence; no other nation seeking to establish democracy has since adopted the same pattern of state institutions. Read Andrew Ellis, "The Indonesian Constitutional Transition: Conservatism or Fundamental Change?," Singapore Journal of International and Comparative Law, 2002, p. 1.

2 Jimly Asshiddiqie, "The Role of Constitutional Courts In The Promotion of Universal Peace and Civilization Dialogues Among Nations", paper was presented in the International Symposium on "the Role of Constitutional Courts on Universal Peace and Meeting of Civilizations", Ankara, April 25, 2007, p. 6-7.

3 Jimly Asshiddiqie, The Role of Constitutional Courts, p. 5.

${ }^{4}$ Moh. Mahfud MD, ini his speech of the World Conference on Constitutional Justice, Cape Town 2009, states, "In the era prior to the amendments to the 1945 Constitution made in 1999-2002, authoritarianism had always been the actual practice, despite the fact that Indonesia adheres to a democratic system in the formal provisions of the Constitution. During this era, many legislations were deemed to be contradictory to the Constitution, but there was only one way to have them amended, namely through legislative review. It was difficult to do considering that the legislative body was politically dominated by the President, either due to his position as a state body which is also involved in the law-making process together with the People's
} 
In the reform era, Indonesia has taken comprehensive reform measures by bringing the sovereignty back to the hand of the people. The peak of such efforts was the amendments to the 1945 Constitution. The amendments were made within four consecutive years, namely the First Amendment in 1999, the Second Amendment in 2000, the Third Amendment in 2001, and the Fourth Amendment in 2002. The objectives of the Amendments were to complement the basic rules of living as a state, which caused the abuse of power in the past. ${ }^{5}$

The First Amendment that stipulated on October 19, 1999, was conducted in the General Meeting of the People's Consultative Assembly in 1999. Under the norms of the amended articles, the objective of the First Amendment to the 1945 Constitution is to restrict the authority of the President and to strengthen the position of the House of People's Representatives as a legislative institution. ${ }^{6}$

The Second Amendment that stipulated on August 18, 2000, was conducted at the Annual Meeting of the People's Consultative Assembly in 2000. This Second Amendment covers issues regarding state territory and regional governance, perfecting the first amendment in the issues about the strengthening of the position of the House of People's Representative, and detailed provisions regarding Human Rights. ${ }^{7}$

The Third Amendment that stipulated on November 9, 2001, was conducted at the Annual Meeting of the People's Consultative Assembly in 2001. The substance for the Third Amendment to the 1945 Constitution covers the provisions regarding the Principles for the foundation of state affairs, state institutions, relations among state institutions, and norms regarding the General Election. ${ }^{8}$

The Fourth Amendment that stipulated on August 10, 2002, was conducted at the Annual Meeting of the People's Consultative Assembly in 2002. The provisions of the amendment in the Fourth Amendment are the provisions regarding state institutions and relations among state institutions, the elimination of the Supreme Consultative Board, provisions regarding education and culture, provisions regarding economics and social welfare, and transitional rules as well as additional rules. ${ }^{9}$

\section{WATER AND FOOD AS HUMAN RIGHTS AND CONSTITUTIONAL RIGHTS}

The function of water and food is indeed essential for human life and can be said to be a necessity that is so important as the needs of living things to oxygen (air). Access to clean water supplies and food has been recognized as a human right described in:

1. Charter for the establishment of the 1946 World Health Organization which states that the enjoyment of the highest attainable standard of health is one of the fundamental rights of every human being.

2. Article 25 Universal Declaration of Human Rights which states: "Everyone has the right to a standard of adequate living for the health and well-being of himself and his family."

3. Article 12 The International Covenant on Economic, Social and Cultural Rights which states: "The States Parties to the present Covenants recognize the right to enjoy the highest attainable standard of physical and mental health."

4. Article 24 (1) of the Convention on the Rights of Child (1989) states: "1. States Parties recognize the right to enjoy the highest standard of health and facilities for the rehabilitation of illness and rehabilitation of health. States Parties shall strive to ensure that children are deprived of the right to access health care services."

In 2000 the UN Committee on Economic, Social and Cultural Rights received a General Comment on the right to health which formulated the normative interpretation of the right to health as stated in Article 12 (1) ICESCR which reads "The States Parties to the present Covenant recognizes the right of everyone to the enjoyment of the highest attainable standard of physical and mental health." The General Comment explain the right to health as an inclusive right that includes not only continuous and appropriate health services but also includes the factors that determine good health, including one of them, is access to safe drinking water. In 2002 the Committee further recognized that access to water was a separate human right.

Unfortunately, the 1945 Constitution did not expressly state that water and food is part of human rights.

Legislative Assembly or his cooptation of all political parties. Such executive heavy configuration placed the President as the determiner of all national political agenda." Moh. Mahfud MD, "Speech" in the World Conference on Constitutional Justice, Cape Town, 2009, p. 2.

${ }^{5}$ Moh. Mahfud MD, "The Role of the Constitutional Court in the Development of Democracy in Indonesia", paper is presented in the World Conference on Constitutional Justice, Cape Town, January 23-24, 2009, p. 1.

${ }_{7}^{6}$ Jimly Asshiddiqie, The Role of Constitutional Courts, p. 5.

7 Jimly Asshiddiqie, The Role of Constitutional Courts, p. 5-6.

8 Jimly Asshiddiqie, The Role of Constitutional Courts, p. 6.

${ }^{9}$ Jimly Asshiddiqie, The Role of Constitutional Courts, p. 6. 
However, some article of the constitution can be part of the rights, such as:

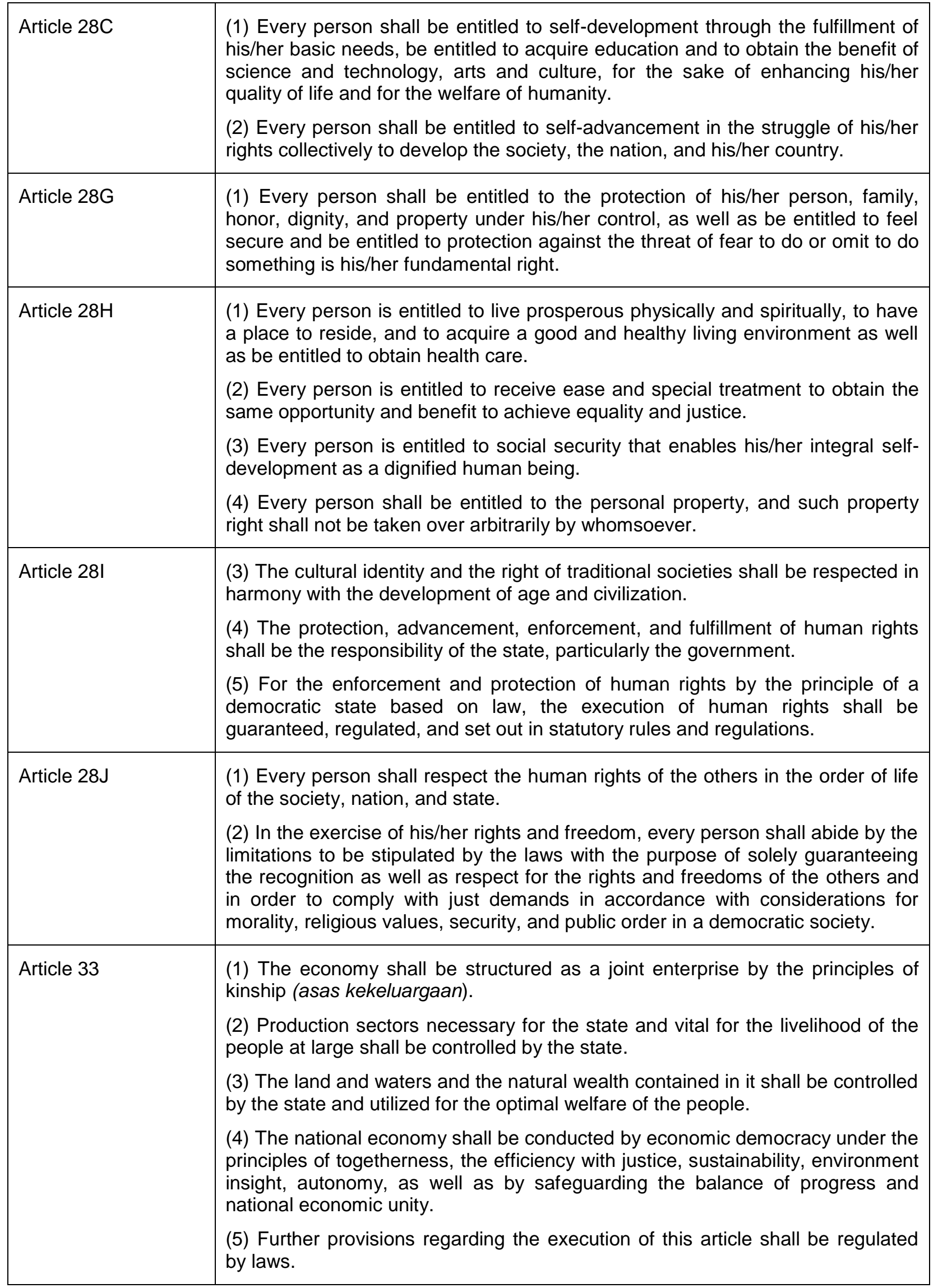

According to Gary F Bell, individual rights in the constitutional context are often perceived as rights that 
protect the individual against the State, and therefore one would think these rights might potentially undermine the State rather than strengthen its unity. It is, however, possible for the constitutional protection of individual rights to symbolically unify a nation thus making its citizens proud of belonging to the country. ${ }^{10}$

The fulfillment of human rights over water and food is the responsibility of the state, meaning that it requires the state to guarantee that everyone can meet the need for water and food. The three aspects of human rights that must be secured by the state, namely respect, protection, and fulfillment, are not only concerned with current needs but also continuity must be guaranteed for the future because it directly concerns human existence. Therefore the state also needs to be actively involved in water and food resources management planning which aims to ensure the availability of water and food for the community. The plan concerns many things including the conservation of water and food sources so that water and food is available sufficiently when water and food is needed by humans;

Water and food right as constitutional rights can be enforced by the court that has jurisdiction to enforce constitutional law. The Third Amendment states that the Constitutional Court has the authority to decide at the first and final instance, the judgment of which is final, to review law against the Constitution.

\section{THE ROLE OF INDONESIAN CONSTITUTIONAL COURT TO ENFORCE WATER AND FOOD RIGHTS}

To safeguard the supremacy of the 1945 Constitution, the Indonesian Constitutional Court then formed as one of the authority organizing court proceedings to enforce the law and justice. ${ }^{11}$ The Constitutional Court of Indonesia has four authorities and one obligation by those mandated by Article 24C (1) and (2) of the 1945 Constitution. The Constitutional Court has the authority to review laws against the Constitution, to judge on authority disputes of state institutions whose authorities are granted by the Constitution, to judge on the dissolution of a political party, and to judge on disputes regarding the result of a general election. The Constitutional Court shall render a judgment on the petition of the People's Representative Council regarding an alleged violation by the President and the Vice President according to the Constitution.

According to Jimly Asshiddiqie, the Constitutional Court of Indonesia is the guardian of the constitution about above mentioned four powers and one obligation. It also brings a consequence to the Constitutional Court of Indonesia to function as the sole interpreter of the constitution. Constitution as the highest law stipulates the state governing based on the principle of democracy and one of the functions of the constitution is to protect human rights which are ensured in the constitution. Human rights become the constitutional right of the citizen. Consequently, the Constitutional Court of Indonesia also has functioned as the guardian of democracy, the protector of constitutional rights, and the protector of human rights. ${ }^{12}$

As an example, on Decision 058-059-060-063/PUU-II/2004 and 008/PUU-III/2005, the Indonesian Constitution Court state that water is a very vital item for human life, even the right to water by the United Nations has been declared a human right, so basically everyone has an interest in the existence of legal provisions that can guarantee and protect human rights to water. So, mutatis mutandis, every Indonesian citizen, as a human being also has a legal standing to question the constitutionality of the Water Law which is felt to be detrimental to him.

"Considering that the recognition of access to water as a human right indicates two things; on the one hand is the recognition of the fact that water is such an important necessity for human life, on the other hand, the need to protect everyone from access to water. For the sake of protection, the right to water needs to be the highest right in the legal field, namely human rights. The problem that arises later is how the position of the

\footnotetext{
${ }^{10}$ Gary F Bell, "Minority Rights and Regionalism in Indonesia -- will Constitutional Recognition Lead to Disintegration and Discrimination?", Singapore Journal of International and Comparative Law, 2001, p. 6.

11 Jimly Asshiddiqie states, "It is necessary to establish a new institution that can play the role as the guardian of the constitution, the balancing power in majoritarian democracy, protector of the citizens' constitutional rights, the final interpreter of the constitution, and as the balancing agent in the checks and balances mechanism among state institutions and among the branches of national power. For that purpose, Indonesia established the Constitutional Court in addition to the already existing Supreme Court." Jimly Asshiddiqie, "Creating a Constitutional Court in a New Democracy", paper presented in Australia, March 2009, p.2-3.

${ }_{12}$ Jimly Asshiddiqie, Menuju Negara Hukum yang Demokratis, (Jakarta: Setjen dan Kepaniteraan MK RI, 2008), p. 39. Petra Stockman wrote, "The Court can become firmly rooted in the Indonesian political system and in Indonesia society and contribute its share to enhancing democracy, rule of law, and human rights protection." Petra Stockman, The New Indonesian Constitutional Court, A Study Into Its Beginnings and First Years of Work (Jakarta: Hans Seidel Foundation, 2008), p. 105.
} 
state about water is a public object or common object that has even been recognized as part of human rights. As with other human rights the position of the state about its obligations arising from human rights, the state must respect, protect, and fulfill it."13

\section{CONCLUSION}

The rights to water and food are not only concerned with protecting the rights that have been enjoyed by someone from violations by others, But also ensuring certainty that human rights must be appreciated. Thus, the protection of rights in this aspect cannot be separated from the fulfillment of recognized rights. Although the right to water and food is not mentioned directly in the 1945 constitution, It is implied that these human rights are contained in the articles of human rights. to uphold the 1945 constitution also constitutes a constitutional court. The court is expected to take a great deal in defending the constitutional rights of citizens, especially on water and food.

\section{REFERENCE LIST}

Asshiddiqie, Jimly. (2009). "Creating a Constitutional Court In a New Democracy," Paper presented in Australia, (March 2009).

Asshiddiqie, Jimly. (2008). Menuju Negara Hukum yang Demokratis, Jakarta: Setjen dan Kepaniteraan MK RI.

Bell, Gary F. (2001). "Minority Rights and Regionalism in Indonesia -- will Constitutional Recognition Lead to Disintegration and Discrimination?", Singapore Journal of International and Comparative Law.

Ellis, Andrew. (2002). "The Indonesian Constitutional Transition: Conservatism or Fundamental Change?," Singapore Journal of International and Comparative Law.

Mahfud MD., Moh. (2009), "The Role of the Constitutional Court in the Development of Democracy in Indonesia," paper in the World Conference on Constitutional Justice, Cape Town, South Africa, 23-24 January 2009.

Stockman, Petra. (2008). The New Indonesian Constitutional Court, A Study Into Its Beginnings and First Years of Work. Jakarta: Hans Seidel Foundation.

${ }^{13}$ Decision 058-059-060-063/PUU-II/2004 and 008/PUU-III/2005 of Indonesian Constitutional Court. 